УДК 575.827:604.6:582.683.2

L.O. SAKHNO ${ }^{1}$, O.Y. KVASKO ${ }^{1}$, Z.M. OLEVINSKA ${ }^{2}$, M.Y. SPIVAK ${ }^{2}$, M.V. KUCHUK ${ }^{1}$

${ }^{1}$ Institute of Cell Biology and Genetic Engineering NAS of Ukraine, Kyiv E-mail:sakhno@icbge.org.ua

2 Zabolotny Institute of Microbiology and Virology NAS of Ukraine, Kyiv

\section{CREATION OF TRANSGENIC BRASSICA NAPUS L. PLANTS EXPRESSING HUMAN ALPHA 2b INTERFERON GENE}

Spring rapeseed transgenic lines expressing human interferon alpha $2 b$ were created by Agrobacteriummediated transformation of aseptic plant leaf explants. The maximum antiviral activity of the leaf extracts reached $4500 \mathrm{IU} / \mathrm{g}$ fresh weight. It was determined that the antioxidant activity and the activity of an enzyme of plant antioxidant system - superoxide dismutase (SOD) - in the leaf tissues of transgenic plants increased compared to controls. There were no correlations between the interferon and antioxidant activities, as well as between SOD and interferon activities. Using the obtained transgenic rapeseed plants with high interferon and antioxidant activities as a feed additive for animals might have preventive effect on their body, increasing resistance to infections of various origins.

(c) L.O. SAKHNO, O.Y. KVASKO, Z.M. OLEVINSKA, M.Y. SPIVAK, M.V. KUCHUK, 2012
Introduction. Over the last decade has intensified research on obtaining plants that synthesize biological molecules with pharmaceutical orientation - antibodies, cytokines, recombinant enzymes, hormones, vaccines for human and farm animals [1-3].

Rapeseed has been successfully grown for the production of animal feed (green mass, silage, haylage, grass meal) in different crops in pure form and in mixtures with other cultures [4]. Cattle have grazed at rapeseed sowing because it has the ability to intensive regrowth after cattle nibble or mowing. For biochemical characteristics rapeseed exceeds most forage crops. In $1 \mathrm{~kg}$ of green mass is usually synthesized up to $30 \mathrm{~g}$ protein, easily digested, a significant amount of ascorbic acid (505-1070 mg/kg for winter cvs and 515-786 mg/ $\mathrm{kg}$ for spring cvs) and carotene $(19,4-42,9 \mathrm{mg} / \mathrm{kg}$ for winter and $20,6-37,4 \mathrm{mg} / \mathrm{kg}$ for spring) $[4,5]$. Along with standard measures, changes in their diet could help to prevent the animal incidence: use as feed additives to green mass rapeseed plants that produce pharmacological proteins and have increased biochemical properties.

There are many rapeseed and rapeseed biotechnological studies on fatty acid changes [6-8], herbicide, pest, disease and abiotic stress resistance [9-13], pharmaceuticals production [14, 15].

Our experiments aimed to create rapeseed plants with human interferon alpha $2 \mathrm{~b}$ gene and to characterize some of their biochemical parameters such as antiviral, antioxidant and superoxide dismutase (SOD) activities.

Materials and methods. Plant material. Aseptic plant leaves (temperature $24{ }^{\circ} \mathrm{C}, 4000-5000$ lux, $16 / 8$ light photoperiod) were used as a raw material. There are spring rapeseed cv Magnat (National Agrarian University of UAAS selection) and cv Magnat (Science-practical center of NAS of Belarus on agriculture selection). Seeds were kindly provided by M.V. Slisarchuk (department of linseed and rapeseed selection and seed production of National Scientific center «Institute of UAAS on agriculture») and by A.M. Shishlova (department of molecular genetics and biotechnology of Institute of genetics and cytology of NAS of Belarus), respectively.

Genetic transformation, bacterium strain and vectors. Transformation of precultivated leaf explants from 3-4 week plants were carried out according to our method proposed earlier [16]. Agrobacterium tumefaciens strain GV3101 was used

ISSN 0564-3783. Цитология и генетика. 2012. № 6 
for plant transformation. Escherichia coli strain XL1Blue was applied for cloning of binary plasmid vectors. Plasmid vectors pICH5290 and pICH17311 were generously donated by Icon Genetics $\mathrm{GmbH}$ (Germany). Restriction endonucleases (REs) and T4 DNA ligase were used with supplied buffers («Fermentas», Lithuania). Bacterial cell transformation, plasmid DNA isolation and electrophoretic analysis were carried out as described in [17]. A short nucleotide sequence containing $B a m \mathrm{HI}$ and $\mathrm{Xba \textrm {I }}$ recognition sites was added to the pICH17311 construct digested with PstI RE. Recombinant $H u I F N-\alpha 2 b$ gene was excised with $N c o$ I and $X b a \mathrm{I}$ REs and ligated into pICH5290 vector predigested with the same REs. The obtained vector were designated as pCB125 (Fig. 1,a) [18].

$P C R$ analysis was carried out with primers INTFOR 5'-ctcctgcttgaaggacag-3' and INTREV 5'-ggagtcctccttcatcag-3' amplifying the 264 bp fragment of $H u I F N-\alpha 2 b$ gene. To detect agrobacterial contamination, primer pair (VirD1-1 5'-atgtcgcaaggcagtaagccca-3' and VirD1-2 5'-ggagtctttcagcatggagcaa-3') was used for amplification of 264 bp fragment of virD1 gene. The reaction mixture contained $1 \mu \mathrm{g}$ of total plant DNA; $0.25 \mu \mathrm{M}$ of each primer; $0.5 \mathrm{u}$ of Taq DNA polymerase and corresponding buffer («Helicon», Russia); $0.5 \mathrm{mM}$ of deoxynucleotide triphosphates (dNTPs) $(0.125 \mathrm{mM}$ each). Amplification was conducted under following conditions: $94{ }^{\circ} \mathrm{C} 5 \mathrm{~min} \rightarrow\left(94^{\circ} \mathrm{C} 30 \mathrm{sec}, 60^{\circ} \mathrm{C}\right.$ $\left.30 \mathrm{sec}, 72{ }^{\circ} \mathrm{C} 30 \mathrm{sec}\right) \times 30 \rightarrow 72{ }^{\circ} \mathrm{C} 5 \min [19]$.

The total soluble protein (TSP) content was measured by the method of Bradford [20]. Extracts from plant leaves were prepared in double volume of $100 \mathrm{mM}$ Tris/ $\mathrm{HCl}$ buffer, $\mathrm{pH}$ 8.0 , containing $5 \mathrm{mM} \mathrm{Na}_{2}$ EDTA, $100 \mathrm{mM} \mathrm{NaCl}$, $10 \mathrm{mM} \beta$-mercaptoethanol, and $2.5 \%$ PVP.

Antiviral activity of leaf extracts. The interferon activity was measured by microtitration method [21] based on the studied extracts ability to protect established piglet testicular cell culture (from cell collection of Kavetsky Institute of Experimental Pathology, Oncology and Radiobiology, NAS of Ukraine) against cytopathic effect of vesicular stomatitis virus (Indiana strain, from collection of Danilo Zabolotny Institute of Microbiology and Virology, NAS of Ukraine).

Antioxidant activity was detected by Semenov et al. [22] with slight modification. Leaves $(300 \mathrm{mg})$ were ground with $1.5 \mathrm{ml}$ of $0.25 \mathrm{M}$ phosphate buf- fer ( $\mathrm{pH}$ 7.4). Homogenate were transferred to Eppendorf tube and centrifuged $10 \mathrm{~min}$ at 4000 $\mathrm{r} / \mathrm{min}$. Reagent mixtures were consisted of 1.5 $\mathrm{ml}$ of $0.25 \mathrm{M}$ phosphate buffer $(\mathrm{pH} 7.4), 0.5$ $\mathrm{ml}$ of $0.8 \mathrm{mM}$ 2,6-dichlorphenolindophenolat $\mathrm{Na}(\mathrm{DCPP} \mathrm{Na}), 0.5 \mathrm{ml} 3.2 \mathrm{mM} \mathrm{FeSO}$ and $0.5 \mathrm{ml}$ supernatant (experiment) or $0.5 \mathrm{ml}$ distil water (control). They were transferred into cuvette $(1 \mathrm{~cm})$ and solution optical density $\left(D_{\tau}\right.$, $510 \mathrm{~nm}$ ) was detected each $30 \mathrm{sec}$ during $5 \mathrm{~min}$. Also solution optical density $\left(\mathrm{D}_{\infty}, 510 \mathrm{~nm}\right)$ was detected when distil water were used instead of $\mathrm{FeSO}_{4} . \mathrm{D}_{\infty}$ characterised total DCPP Na oxidation. As indexes of plant material antioxidant activity were considered the means of inhibition constant $\left(\mathrm{K}_{\mathrm{i}}\right)$ of DCPP Na oxidation. They were calculated by formula:

$$
K_{i}=\frac{K_{\text {control }}-K_{\text {exp }}}{C}
$$

$K_{\text {control }}$ and $K_{\text {exp }}$ were constant of speed oxidation of DCPP $\mathrm{Na}$ in control and experimental solution, respectively, $\mathrm{ml} / 1 \mathrm{~min}$. They were rated as the slope on the graph of the natural logarithm $\Delta \mathrm{D}_{\tau}\left(\Delta \mathrm{D}_{\tau}=\mathrm{D}_{\infty}-\mathrm{D}_{\tau}\right)$ from time. $C-$ plant material concentration in cuvette, $\mathrm{mg} / \mathrm{ml}$.

Superoxide dismutase (SOD) activity. Photochemical oxidation of nitro blue tetrazolium method were used for determination of SOD activity [23]. Processed liquid nitrogen plant material $(100 \mathrm{mg})$ in Eppendorf tube $(1.5 \mathrm{ml})$ was rubbed with $1 \mathrm{ml}$ of Tris- $\mathrm{HCl}$ buffer $(\mathrm{pH} \mathrm{8.0)}$ and was centrifuged at $13000 \mathrm{~g}\left(4^{\circ} \mathrm{C}\right)$ during $15 \mathrm{~min}$. Supernatant was used for analyses. Reaction was held in Eppendorf tube $(1.5 \mathrm{ml})$. One tube for each probe was retained in the dark. The other was illuminated by white light lamp (fluorescent lamp T5/G5, model ELI-230A-T5-8W) during 5 min. in the thermostat at $23{ }^{\circ} \mathrm{C}$. The solution optical density of illuminated probe was measured at $550 \mathrm{~nm}$ («BioPhotomether Eppendorf», Germany) versus optical density of dark probe. Null probe had in its composition leaf extract. The calculation was carried out by the formula:

$$
\begin{aligned}
& \mathrm{SOD}(\text { relative unit } / \mathrm{ml} \text { suspension })= \\
& \quad=\left(\mathrm{OD}_{1} / \mathrm{OD}_{2}-1\right)[\mathrm{DF}],
\end{aligned}
$$

$\mathrm{OD}_{1}$ - optical density of null probe; $\mathrm{OD}_{2}-$ optical density of experimental probe; DF - dilution factor $=$ reaction mixture volume, $\mathrm{ml} /$ used plant 

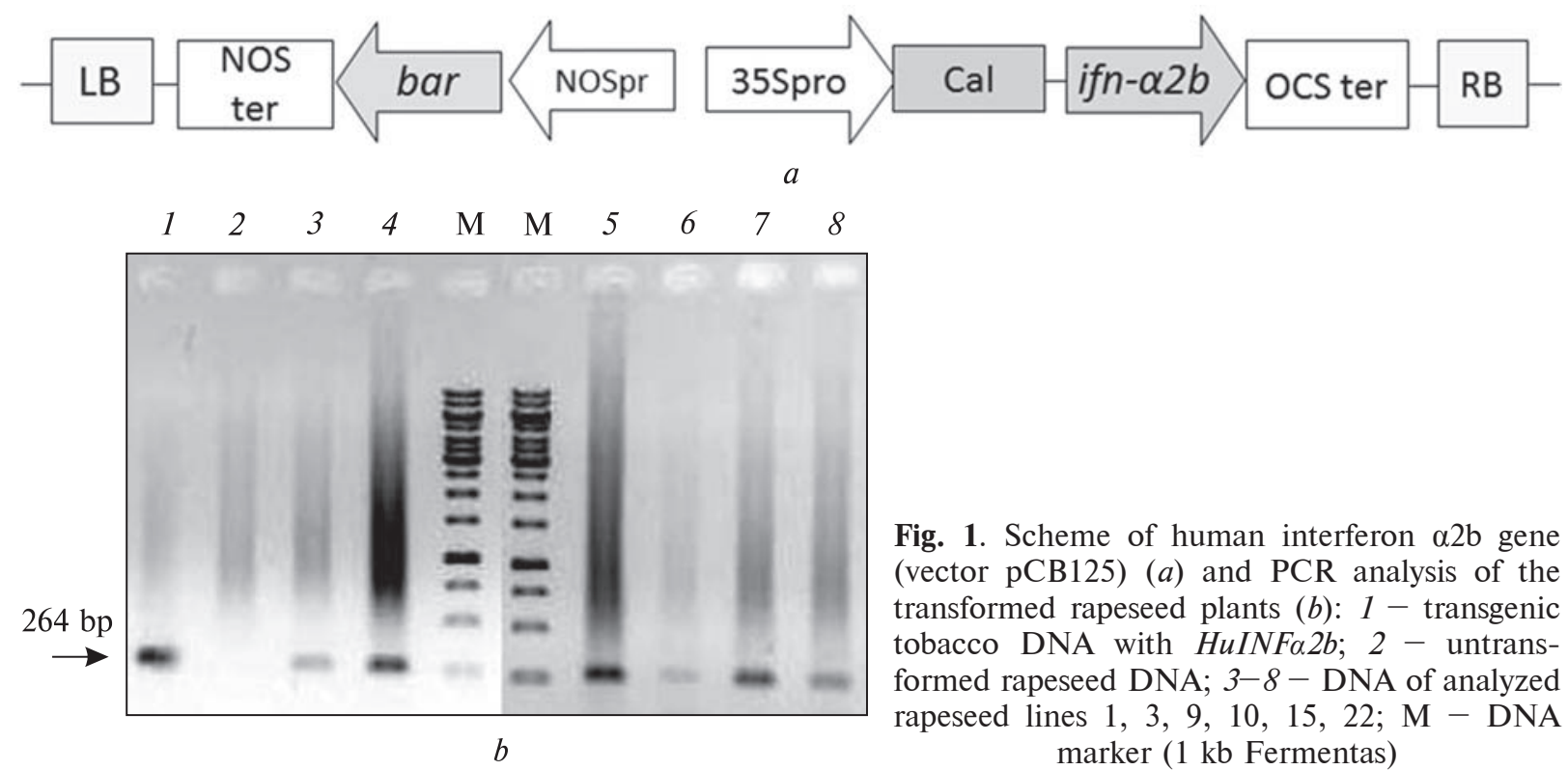

Fig. 1. Scheme of human interferon $\alpha 2 b$ gene (vector pCB125) $(a)$ and PCR analysis of the transformed rapeseed plants $(b): 1-$ transgenic tobacco DNA with HuINFa2b; 2 - untransformed rapeseed DNA; 3-8 - DNA of analyzed rapeseed lines $1,3,9,10,15,22 ; \mathrm{M}$ - DNA

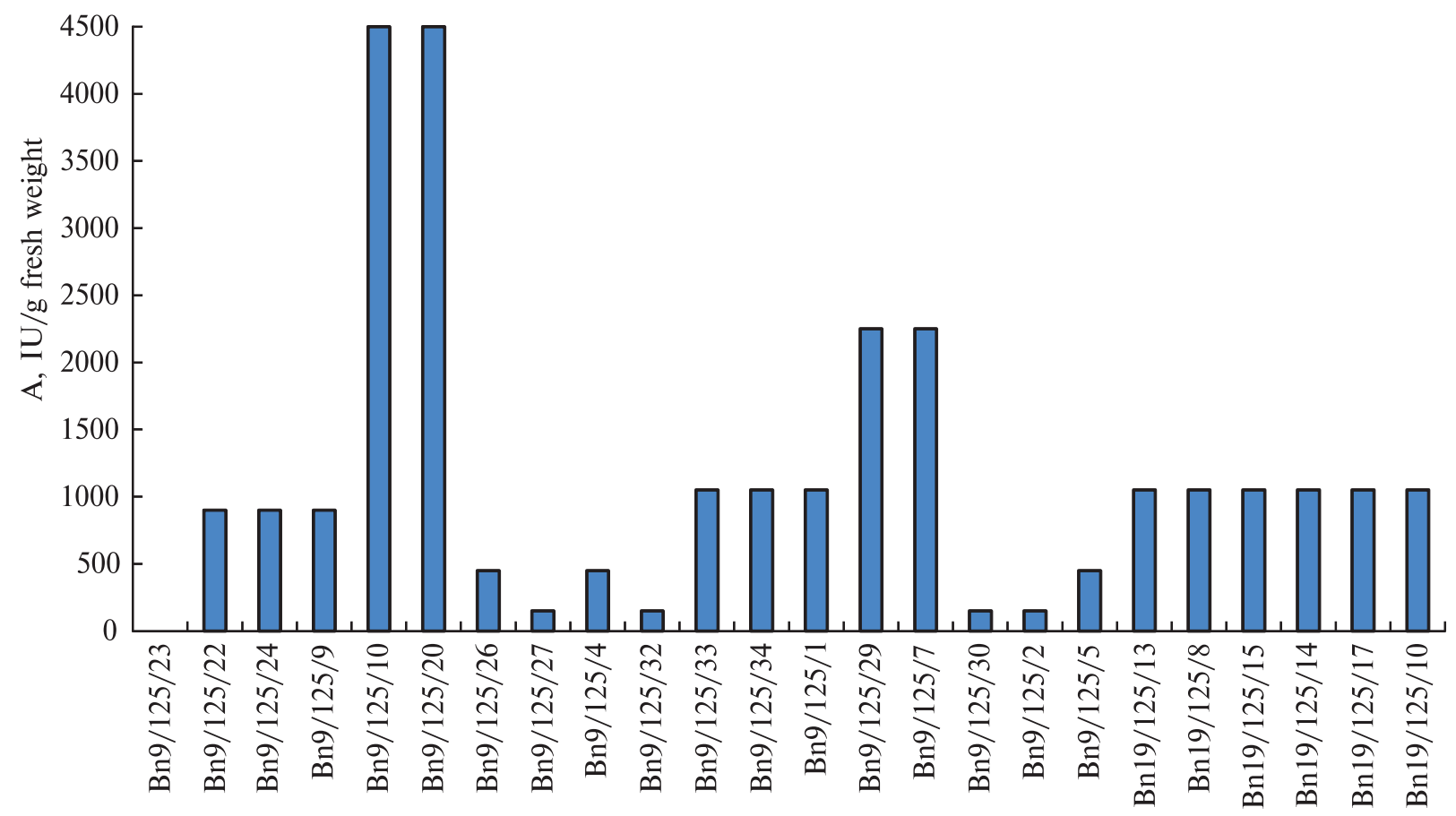

Fig. 2. Interferon activity in leaves of primary rapeseed transformants

extract volume, ml; SOD activity was expressed in relative unit/mg protein.

The statistical design was carried on for the obtained results in way of interferon antiviral activity, antioxidant and SOD activity measurement. Dif- ferences from control values were significant at $\mathrm{P}<$ $<0.05$ according to Duncan's multiple range test.

Results and discussion. The first regenerants were formed in selective condition (phosphinothricin, $5 \mathrm{mg} / \mathrm{l}$ ) after $5-6$ weeks from the beginning ISSN 0564-3783. Цитология и генетика. 2012. № 6 
of experiments. It took 7-14 days for complete formation of shoots. Root formation took place without additional induction after regenerant passage on MS culture medium [24] without hormone during 2-3 weeks.

As a result of experiments 52 phosphinothricin resistant rapeseed lines were created. There are 18 lines on basis of cv Magnat (National Agrarian University of UAAS selection) and 32 ones derived from cv Magnat (Science-practical center of NAS of Belarus on agriculture selection).

Plant lines were propagated in vitro by graftage and tested for HuINFa $2 b$ gene presence and Agrobacterium contamination absence. PCR analyses detected presence of target DNA in obtained plants (Fig.1, b). Bacterial contamination was absent.

Aseptic leaves of transformed plants were used for protein extraction to test the activity of human interferon $\alpha 2 b$. It was determined difference of interferon activity between transgenic line extracts (Fig. 2).

Interferon activity in rapeseed primary transformants growing under in vitro conditions varied from complete absence (line Bn9/125/23) to $4500 \mathrm{IU} / \mathrm{g}$ fresh weight. The maximum protein activity for this group of plants was recorded for the two lines - Bn9/125/20 and $\mathrm{Bn} 9 / 125 / 10$. In seven rapeseed lines interferon activity was lower than $500 \mathrm{IU} / \mathrm{g}$ fresh weight. In most lines (14) it varied from 900 up $2250 \mathrm{IU} / \mathrm{g}$ fresh weight.

Rapeseed lines with high interferon activity were planted into soil under greenhouse conditions. They are easily adapted, and blossoms without anomalies formed viable seeds.

Four weeks after planting the parts of second from apex leaf were extracted for interferon activity evaluation. It was found that in the lines Bn9/125/20 and $\mathrm{Bn} 9 / 125 / 10$ interferon activity remained at the same level as under aseptic culture.

To study the changes in the adaptation ability of obtained rapeseed plants biochemical parameters such as leaf tissue antioxidant activity and the activity of one of the enzymes of plant antioxidant system - superoxide dismutase - were investigated. It was shown that some transgenic rapeseed lines had increased antioxidant activity (Fig. 3).

Antioxidants protect cell structures from damage by free radicals [25]. The main natural

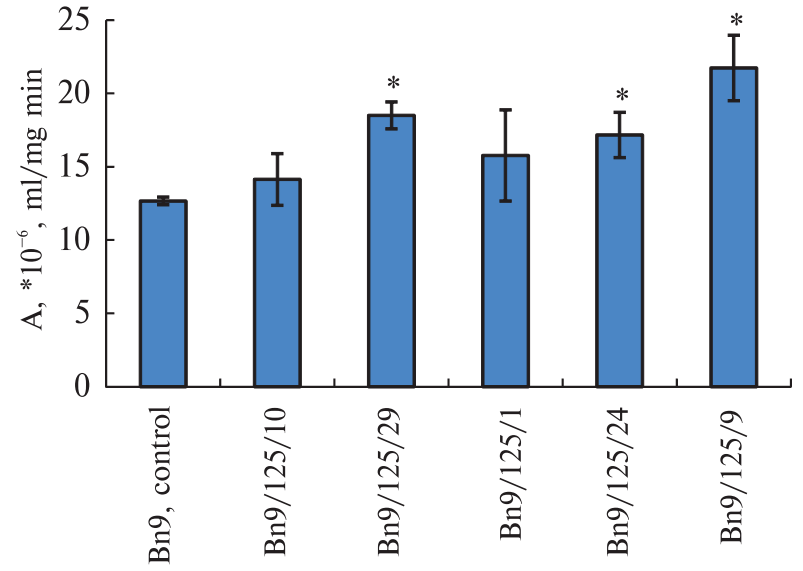

Fig. 3. Leaf tissue antioxidant activity in control (Bn9, cv Magnat) and carrying HuINFa2b gene biotechnological rapeseed lines

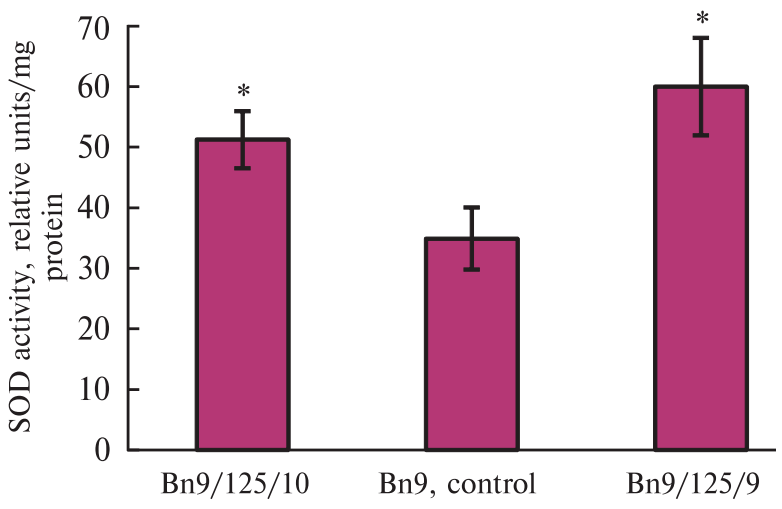

Fig. 4. SOD activity in leaf tissue of aseptic rapeseed plants

antioxidants are vitamins $\mathrm{E}$ and $\mathrm{C}$, fatty acids, polyphenols. Increased antioxidant activity in plant tissues positively affects their ability to resist stress factors of various origins [26, 27].

Rapeseed leaves were shown to have antioxidant activity, which exceeds that in many traditionally cultivated plants [28]. In recalculation on ascorbic acid it was $710 \mu \mathrm{g} / \mathrm{g}$ raw weight. This index was lower for the letter lettuce and spinach (446 and $434 \mu \mathrm{g} / \mathrm{g}$ raw weight, respectively), in red cabbage leaves was almost twice higher (1217 $\mu \mathrm{g} / \mathrm{g}$ raw weight).

Using the obtained rapeseed plants with high antioxidant activity as a feed additive for animals should have preventive effect, increasing resistance to infections of various origins.

Comparison of $\alpha 2 \mathrm{~b}$ interferon and antioxidant activity in leaf tissues of plants grown under 
Antioxidant and interferon activities in leaf tissue of biotech rapeseed lines with $\mathrm{HuINF}$ $2 \mathrm{~b}$ gene

\begin{tabular}{l|c|c}
\hline \multicolumn{1}{c|}{ Lines } & $\begin{array}{c}\text { Antioxidant } \\
\text { activity } \times 10^{-6}, \\
\mathrm{ml} / \mathrm{mg} \mathrm{min}\end{array}$ & $\begin{array}{c}\text { Interferon } \\
\text { activity, IU/g } \\
\text { fresh weight }\end{array}$ \\
\hline Bn9, control & $12,67 \pm 0,27$ & 0 \\
Bn9/125/10 & $14,13 \pm 1,76$ & 4500 \\
Bn9/125/29 & $18,50 \pm 0,82$ & 2250 \\
Bn9/125/1 & $15,77 \pm 3,11$ & 1050 \\
Bn9/125/24 & $17,17 \pm 1,55$ & 900 \\
Bn9/125/9 & $21,73 \pm 2,23$ & 900 \\
\hline
\end{tabular}

aseptic conditions showed that there was no correlation between these two indicators (Table).

Formasan (violet color substance) formation occured as a result of photochemical oxidative reaction of nitro blue tetrazolium. In the null probe oxidation was complete and plant extracts could inhibit formasan formation due to SOD activity. SOD activity calculations showed that it increased in the analyzed biotech rapeseed lines compared with the control one (Fig. 4).

In transformed rapeseed plants, which expressed the wheat mitochondrial Mn SOD ( $M n$ SOD3.1 gene), an increased ability to resist stress of various origin was observed [29]. They germinated in laboratory and field conditions faster than control plants and were kept drought, the influence of high and low temperatures. Sensitivity to stress of our obtained transgenic rapeseed plants needs further investigation.

It should be noted that both SOD activity and antioxidant activity in leaf tissues of Bn9/125/9 line was higher than in controls. Increased antioxidant activity was not observed for Bn9/125/10 line, although SOD activity in its tissues was raised (Fig. 2 and 4). Perhaps the increased SOD activity in this case was leveled by a decrease of some other component of the antioxidant system (e.g. changing the content of ascorbic acid or tocopherol, the activity of enzymes catalase or peroxidase, etc.).

Conclusions. We obtained transgenic rapeseed plants, which are characterized by the presence in their nuclear genome of human interferon $\alpha 2 b$ gene. We showed that biotechnological lines had different activity of introduced gene, the maximum value reached 4,500 IU/g fresh weight. Using the obtained plants with high antioxidant activity as a feed additive for animals might have preventive effect, increasing resistance to infections of various origins.

Created rapeseed lines possessed also such biochemical characteristics as high antioxidant activity of leaf tissue under in vitro cultivation and increased activity of antioxidant system enzyme superoxide dismutase. This gives reason to hope for increased resistance of transgenic lines to biotic and abiotic stresses.

Supported by grant of GASIIU, № UkrISTEI $0111 U 007598$ and NASU grant, № UkrISTEI $0110 U 006061$.

Л.А. Сахно, Е.Ю. Кваско,

3.М. Олевинская, Н.Я. Спивак, Н.В. Кучук

СОЗДАНИЕ ТРАНСФОРМИРОВАННЫХ PAСТЕНИЙ BRASSICA NAPUS L.,

ЕКСПРЕССИРУЮЩИХ РЕКОМБИНАНТНЫЙ АЛЬФА 2b ИНТЕРФЕРОН ЧЕЛОВЕКА

Методом агробактериальной трансформации листовых эксплантов асептических растений ярового рапса получены линии, экспрессирующие альфа $2 \mathrm{~b}$ интерферон человека. Максимальная противовирусная активность экстрактов листьев достигала $4500 \mathrm{ME} /$ сырого веса. Установлено, что антиоксидантная активность и активность одного из ферментов антиоксидантной системы растений - супероксиддисмутазы (СОД) - в тканях листьев трансгенных растений повышена по сравнению с контрольными. Не выявлено корреляции как между активностью интерферона и антиоксидантной активностью, так и между активностью интерферона и активностью СОД. Использование полученных трансгенных растений рапса с высокой активностью интерферона и повышенной антиоксидантной активностью как добавки к кормам животных могло бы оказывать профилактическое влияние на их организм, повышая устойчивость к различным инфекциям.

Л.О. Сахно, О.Ю. Кваско,

3.М. Олевінська, М.Я. Спивак, М.В. Кучук

СТВОРЕННЯ ТРАНСФОРМОВАНИХ РОСЛИН BRASSICA NAPUS L., ЯKI ЕКСПРЕСУЮТЬ РЕКОМБІНАНТНИЙ АЛЬФА 2b ІНТЕРФЕРОН ЛЮДИНИ

Методом агробактеріальної трансформації листових експлантів асептичних рослин ярого ріпака отримано лінії, що експресують альфа $2 \mathrm{~b}$ інтерферон людини. Максимальна противірусна активність екстрактів листків сягала 4500 МО/сирої

ISSN 0564-3783. Цитология и генетика. 2012. № 6 
ваги. Встановлено, що антиоксидантна активність i активність одного з ферментів антиоксидантної системи рослин - супероксиддисмутази (СОД) в тканинах листків трансгенних рослин підвищена в порівнянні 3 контрольними. Не виявлено кореляції ні між активністю інтерферона і антиоксидантною активністю, ні між активністю інтерферона і активністю СОД. Використання отриманих трансгенних рослин ріпака 3 високою активністю інтерферона та підвищеною антиоксидантною активністю як добавки до кормів тварин мало б профілактично впливати на їхній організм, підвищуючи стійкість до інфекцій різного походження.

\section{REFERENCES}

1. Daniel H., Singh N.D., Mason H., Streatfield S.J. Plant-made vaccine antigens and biopharmaceuticals // Trends in Plant Science. - 2009. 14, № 12. - P. 669-679.

2. Joensuu J.J., Niklander-Teeri V., Brandle J.E. Transgenic plants for animal health: plant-made vaccine antigens for animal infectious disease control // Phytochem. Rev. - 2008. - 7. P. 553-577.

3. Scheludko Y.V. Recent advances in plant biotechnology and genetic engineering for production of secondary metabolites // Cytology and Genetics. - 2010. - 44, № 1. - C. 65-75.

4. Goltsov A.A., Kovalchuk A.A., Abramov B.Ph., Milaschenko H.Z. Rapeseed. - M.: Kolos, 1983. $192 \mathrm{p}$.

5. Vehov B.N., Gubanov I.A., Lebedeva G.Ph. The cultivated plants of USSR. - M.: Misl, 1978. $336 \mathrm{p}$.

6. Scarth R., Tang J. Modification of Brassica oil using conventional and transgenic approaches // Crop. Sci. - 2006. - 46. - P. 1225-1236.

7. Murphy D.J. Molecular breeding strategies for the modification of lipid composition // In Vitro Cell Dev. Biol. - Plant. - 2006. - 42. - P. 89-99.

8. Sakhno L.O. Variability in the fatty acid composition of rapeseed oil : Classical breeding and biotechnology // Cytology and Genetics. 2010. - 44, № 6. - P. 389-397.

9. Senior I.J., Dale P.J. Herbicide-tolerant crops in agriculture: oilseed rape as a case study // Plant Breed. - 2002. - 121. - P. 97-107.

10. Stewart C.N.Jr., Adang M.J., All J.A., Raymer P.L., Ramachandra S., Parrott W.A. Insect control and dosage effects in transgenic rapeseed containing a synthetic Bacillus thuringiensis cryIAC gene // Plant Physiol. - 1996. - 112. - P. 115-120.

11. Melander M., Ehman I., KamnertI., Strömdahl A.-Ch. Pea lectin expressed transgenically in oilseed rape reduces growth rate of pollen beetle larvae// Transgenic Res. - 2003. - 12. - P. 555-567.

12. Orison R., Grezesbesse B., Schneider M., Lucante N., Olsen L., Leguay J.J., Toppan A. Field tolerance to fungal pathogens of Brassica napus constitutively expressing a chimeric chitinase gene// Nature Biotech. - 1996. - 14. - P. 643-646.

13. Truksa M., Vrinten P., Qiu X. Metabolic engineering of plants for polyunsaturated fatty acid production // Mol. Breed. - 2009. - 23, № 1. - P. 111.

14. Hüsken A., Baumert A., Miskowski C., Becker H.C., Dieter S., Möller C. Resveratrol glucoside (Piceid) synthesis in seeds of transgenic oilseed rape (Brassica napus L.) // Theor. Appl. Genet. - 2005. 111. - P. 1553-1562.

15. Liu J.-W., DeMichele S., Bergana M. et al. Characterization of oil exhibiting high $\gamma$-linolenic acid from a genetically transformed canola strain // J. Amer. Oil. Chem. Soc. -2001. - 78, № 5. P. 489-493.

16. Sakhno L.O., Gocheva E.A., Komarnitskii I.K., Kuchuk N.V. Stable expression of the promotorless bar gene in transformed rapeseed plants // Cytology and Genetics. - 2008. - 42, № 1. - P. 16-22.

17. Sambrook J., Fritsch E.F., Maniatis T. Molecular cloning : A laboratory manual (2nd ed.) // Cold Spring Harbor Laboratory Press. - New York, 1989.

18. Gerasymenko I.M., Lypova N.M., Sakhno L.A., Shcherbak N.L., Sindarovska Y.R., Bannikova M.A., Sheludko Y.V., Kuchuk N.V. Obtaining and analysis of tobacco, lettuce and rape plants transformed with human interferon alfa $2 b$ gene // Factors of Experimental Evolution of Organisms / Ed. V.A. Kunakh. - Kiev : Logos. - 2009. - 7. - P. 274279.

19. Gerasymenko I.M., Sakhno L.O., Mazur M.G., Sheludko Y.V. Multiplex PCR assay for detection of human interferon alpha2b gene in transgenic plants // Cytology and Genetics. - 2012. - 46, № 4. - P. 3-8.

20. Bradford M.M. A rapid and sensitive method for the quantitation of microgram quantities of protein utilizing the principle of protein-dye binding // Anal. Biochem. - 1976. - 72, № 2. - P. 248254.

21. Rubinstein S., Familletti Ph., Petska S. Convenient assay for interferons // J. Virol. - 1981. - 37, № 5. - P. 755-758.

22. Semenov V.L., Yarosh A.M. A method for determination of antioxidation activity of the biological material // Ukr. Biochem. J. - 1985. - 57, № 3. P. 50-52.

23. Beyer W.F., Fridovich I. Assaying for superoxide 
dismutase activity some large consequences of minor changes in conditions// Anal. Biochem. 1987. - 161, № 2. - P. 559-566.

24. Murashige T., Skoog F. A revised medium for rapid growth and bioassays with tobacco tissue cultures // Physiol. Plant. - 1962. - 15. - P. 473-497.

25. Maksimov I.V., Cherepanova E.A. Pro-/antioxidant System and Resistance of Plants to pathogens // Uspekhi sovremennoi biologii (Advances of Current Biology, Russian). - 2006. - 126, № 3. P. 250-261.

26. Kim Y.-H., Lim S., Yang K.-S. Expression of Arabidopsis NDPK2 increases antioxidant enzyme activities and enhances tolerance to multiple environmental stresses in transgenic sweet potato plants // Mol. Breed. - 2009. - 24. - P. 233-244.
27. Yang L., Tang R., Zhu J. Enhancement of stress tolerance in transgenic tobacco plants constitutively expressing AtIpk $2 b$, an inositol polyphosphate 6-/3-kinase from Arabidopsis thaliana // Plant Mol. Biol. - 2008. - 66. - P. 329-343.

28. Chen I.-C., Chang H.-C., Yang H.-W., Chen G. $-L$. Evaluation of total antioxidant activity of several popular vegetables and chinese herbs: a fast approach with $\mathrm{ABTS} / \mathrm{H}_{2} \mathrm{O}_{2} / \mathrm{HRP}$ system in microplates// J. Foog and Grug Anal. - 2004. 12, № 1. - P. 29-33.

29. Gusta L.V., Benning N.T., Wu G. et al. Superoxide dismutase: an all-purpose gene for agri-biotechnology // Mol. Breed. - 2009. - 24. - P. 103-115.

Received 17.01.12 